Dermatology 2008;216:363

DOI: $10.1159 / 000117708$

\title{
Multiple Eruptive Dermatofibromas in a Patient Receiving Efalizumab
}

Jorge Santos-Juanes a , Pablo Coto-Segura a , Susana Mallo , Cristina Galache ${ }^{\mathrm{b}}$, Jorge Soto ${ }^{\mathrm{c}}$

a Service of Dermatology II, Hospital Universitario Central de Asturias, Universidad de Oviedo, Oviedo, ${ }^{\text {b}}$ Service of

Dermatology, Hospital de Cabueñes, Gijón, and ' Departament of Dermatology, Universidad del País Vasco, Bilbao, Spain

\section{Key Words}

Multiple eruptive dermatofibromas $\cdot$ Efalizumab $\cdot$ Psoriasis

Multiple eruptive dermatofibromas (MED) are very rare and usually have been associated with autoimmune diseases, immunosuppressant therapy, hematologic malignancy and other conditions [1]. We present the case of a 44-year-old woman with psoriasis who developed MED while undergoing efalizumab treatment. To our knowledge this association is a novel finding that has not previously been described $[2,3]$.

\section{Report of Case}

A 44-year-old Caucasian woman with recalcitrant psoriasis was treated with efalizumab $(1 \mathrm{mg} / \mathrm{kg}$ once a week) after several therapeutic failures with other agents. After 8 months she suddenly developed 7 erythematous, brownish papules on both extremities.

Physical examination revealed 7 firm, brownish, dome-shaped nontender papules ranging from 5 to $10 \mathrm{~mm}$ in diameter with lateral dimpled signs on the thighs ( 3 on the right and 4 on the left. Excision biopsy of 1 papule on the right thigh showed a poorly demarcated dermal nodule composed of tightly interdigitating fascicles of spindle-shaped fibrohistiocytic cells. In the peripheral part of the dermal tumor, the dermal collagen was entrapped by the fibrohistiocytic cells. Special stains for infectious agents were negative. The immunohistochemical study revealed that many of the lesion cells were positive for factor XIIIa.

Laboratory findings were either normal or negative for the following: complete blood cell count; metabolic and hepatitis panels; erythrocyte sedimentation rate; anti-HIV antibody, and levels of antinuclear antibody, double-stranded DNA antibody, immunoglobulins and thyroid-stimulating hormone.

Treatment was suspended and at 6 months no new lesions were found.

\section{KARGER}

() 2008 S. Karger AG, Basel

Fax +41 613061234

E-Mail karger@karger.ch

www.karger.com
Accessible online at:

www.karger.com/drm

\section{Comment}

Although dermatofibromas (DFs) are very common, their pathogenesis is poorly understood. It has recently been proposed that this should be regarded as an immunoreactive process, mediated by dermal antigen-presenting cells that trigger an abortive immune response to as yet unidentified antigenic stimuli. According to this hypothesis, the development of MED in immunodeficient states could be facilitated by the inhibition of downregulatory T cells; alternatively, multiple DFs could develop as an exaggerated response to a putative pathogen that could not be cleared by the suppressed immune system [4-6].

Efalizumab (anti-CD11a) is a humanized monoclonal antibody, which blocks multiple T-cell-dependent functions involved in the pathogenesis of psoriasis, including $\mathrm{T}$ cell activation and migration to the skin provoking a partial immunosuppressed state [7].

We believe that this combination is not just coincidental and that the development of DF can be attributed to the medication. In a review of the literature we found only 1 patient with psoriasis receiving prednisolone and ultraviolet $B$ phototherapy who developed MED, but the authors attributed the eruption of DF to the HIV infection which the patient suffered [8]. Moreover, the development of new DFs stopped after immunosuppressive therapy had been discontinued in our patient.

As dermatologists prescribing new biological drug therapies we should be alert to the appearance of new side effects not found in clinical trials.

\section{References}

$\checkmark 1$ Huang PY, Chu CY, Hsiao CH: Multiple eruptive dermatofibromas in a patient with dermatomyositis taking prednisolone and methotrexate. J Am Acad Dermatol 2007;57:S81-S84.

2 Thielen AM, Kuenzli S, Saurat JH: Cutaneous adverse events of biological therapy for psoriasis: review of the literature. Dermatology 2005;211:209-217.

- 3 Leonardi CL, Toth D, Cather JC, Langley RG, Werther W, Compton P, Kwon P, Wetherill G, Curtin F, Menter A: A review of malignancies observed during efalizumab (Raptiva ${ }^{\circledR}$ ) clinical trials for plaque psoriasis. Dermatology 2006;213:204-214.

4 Nestle FO, Nickoloff BJ, Burg G: Dermatofibroma: an abortive process mediated by dermal dendritic cells? Dermatology 1995;190:265-268.

5 Kanitakis J, Carbonnel E, Delmonte S, Livrozet J, Faure M, Claudy A: Multiple eruptive dermatofibromas in a patient with HIV infection: case report and literature review. J Cutan Pathol 2000;27:54-56.

-6 Niiyama S, Katsuoka K, Happle R, Hoffmann R: Multiple eruptive dermatofibromas: a review of the literature. Acta Derm Venereol 2002;82: 241-242.

7 Raptiva (efalizumab) (package insert). South San Francisco, Gevenetch Inc, 2005.

8 Armstrong DKB, Irving A, Walsh MY: Multiple dermatofibromas in a patient with HIV infection. Clin Exp Dermatol 1995;20:474-476.

Jorge Santos-Juanes

Service of Dermatology II

Hospital Universitario Central de Asturias

ES-33006 Oviedo (Spain)

Tel. +34 985106 100, Fax +34 985273 657, E-Mail jsantosj@hca.es 